University of Wollongong

Research Online

Faculty of Law, Humanities and the Arts Papers (Archive)

Faculty of Arts, Social Sciences \& Humanities

$1-1-2019$

Corporate Social Responsibility, Human Rights and Clothing Workers in Bangladesh and Malaysia

Vicki D. Crinis

University of Wollongong, vcrinis@uow.edu.au

Follow this and additional works at: https://ro.uow.edu.au/lhapapers

Part of the Arts and Humanities Commons, and the Law Commons

Research Online is the open access institutional repository for the University of Wollongong. For further information contact the UOW Library: research-pubs@uow.edu.au 


\title{
Corporate Social Responsibility, Human Rights and Clothing Workers in Bangladesh and Malaysia
}

\author{
Abstract \\ The brand-name fashion industry creates high levels of competition in developing countries, leading to \\ labour exploitation and human rights abuse. The 2013 World Investment Report found that pushing prices \\ down in global value chains has led to "significant negative social and environmental impacts". In \\ response, fashion corporations and retail giants introduced codes of conduct to address consumer \\ concerns and stop any damage to brand reputation. Corporate Social Responsibility (CSR) has had some \\ success in preventing child labour but little if any victory in allowing workers the right to organise and \\ bargain collectively. In fact, CSR has been blamed for undermining the role of trade unions and privatising \\ labour rights. In this article, I trace the history of CSR from shareholders to a human rights model. I \\ highlight tensions between national accumulation policies, company profits, shareholders and CSR on the \\ one hand, and migrant workers and human rights on the other.

\section{Disciplines} \\ Arts and Humanities | Law

\section{Publication Details} \\ Crinis, V. (2019). Corporate Social Responsibility, Human Rights and Clothing Workers in Bangladesh and \\ Malaysia. Asian Studies Review, 43 (2), 295-312.
}




\title{
Corporate Social Responsibility, Human Rights and Clothing Workers in Bangladesh and Malaysia
}

\author{
Vicki Crinis* \\ University of Wollongong
}

\begin{abstract}
The brand-name fashion industry creates high levels of competition in developing countries, leading to labour exploitation and human rights abuse. The 2013 World Investment Report found that pushing prices down in global value chains has led to "significant negative social and environmental impacts". In response, fashion corporations and retail giants introduced codes of conduct to address consumer concerns and stop any damage to brand reputation. Corporate Social Responsibility (CSR) has had some success in preventing child labour but little if any victory in allowing workers the right to organise and bargain collectively. In fact, CSR has been blamed for undermining the role of trade unions and privatising labour rights. In this article, I trace the history of CSR from shareholders to a human rights model. I highlight tensions between national accumulation policies, company profits, shareholders and CSR on the one hand, and migrant workers and human rights on the other.
\end{abstract}

\section{KEYWORDS}

Fashion; brand names; Corporate Social Responsibility (CSR); anti-sweatshop movement; migrant labour; Malaysia; Bangladesh

\section{Introduction}

Since the 1990s the naming and shaming strategies of the anti-sweatshop movement have made it more difficult for brand-name clothing manufacturers to ignore the exploitation of workers in their commodity chains. Corporate governance - taking into account both shareholders' and stakeholders' interests - has widely adopted Corporate Social Responsibility (CSR) approaches to deal with a range of issues around labour and the environment. While labour employed by suppliers is outside the brand's direct control, brands have nevertheless tried to impose codes of conduct along their supply lines. In practice, the brand-name buyer (sourcing company) sets the codes to protect workers in their supply chains. The codes usually include the freedom to associate and the right to bargain collectively, the elimination of forced or compulsory labour, the abolition of child labour, and the elimination of discrimination in respect of employment and occupation. Supply factories are monitored on an annual basis before contracts are assigned to their factories. As one factory manager in Malaysia explained in an interview, "We must make sure the overtime is in order, we have no workers under 18 years of age, and there is no discrimination against the workers. They send the auditor once a year to check" (personal communication, 2014).

The pressure to comply with brand-name pressure to meet CSR provisions is real, but it is difficult to police. Factories are ordered in "tiers". Tier-one factories are always monitored, but these factories draw in turn on suppliers for dyeing, embroidery and pressing, and they are not usually monitored. Even in tier-one factories, some rights are easier to enforce than others. It is highly unlikely that workers under the age of 18 would be employed in a tier-one factory because proof of age must be produced at the recruitment stage. Overtime work can be made

*cONTACT vcrinis@uow.edu.au 
transparent by asking the workers to sign an overtime sheet indicating that they agree to work overtime. The right to join unions may not be so easy, though. As Tsing (2009) points out, private regulation of global brand names and retailers under the neoliberal ethos does not always reach workers across supply chains, especially when these workers are non-citizens or short-term contract workers. The conditions set out under national labour standards, for example, may have several regulations protecting the rights of unions to organise, but migrants may have conditions written into their employment contracts that prevent them from joining associations. My research, conducted from 2008 to 2014 in the Bangladeshi and Malaysian clothing industry, found that codes of conduct did little to assist the thousands of migrant workers laid off ahead of citizen workers during the Asian Financial Crisis and that codes of conduct are not a lot of practical use.

Numerous scholars have attempted to understand the successes and failures of CSR (Bair \& Palpacuer, 2015; Esbenshade, 2012; Hale \& Willis, 2007; Prieto-Carron, 2008; Ruwanpura, 2015; Rahim, 2017; Santoro, 2015; Siddiqi, 2009). Some scholars found that corporate social responsibility initiatives had the potential to work, but had not moved past their initial introduction. Other scholars found CSR codes were only beneficial to workers in tier-one factories or where the country had a firm rule of law, and the supplier established a relationship with the buyers (Locke, Qin, \& Brause, 2007). Others found that the codes were too general and did not address the gendered nature of the industry (Collins, 2014) or that there were local and national factors to consider (Lund-Thomsen \& Coe, 2015). Many saw problems with monitoring: supply factories might adopt the codes of conduct, but buyer audits had little chance of discovering labour abuse or tracking rights concerned with freedom of association (Marx and Wouters, 2016; DeNeve, 2008; Rahim, 2017). Furthermore, the audit-based data collated by auditors often worked to the benefit of the retailers. Brand-name buyers can read the data to increase control over their suppliers and manage business risks (LeBaron \& Lister, 2015, p. 22). While the literature identifies both positives and negatives in the operation of CSR, the most recent studies have highlighted a supplier perspective whereby supply managers viewed CSR as a compliance issue rather than a development strategy designed to increase wages and improve conditions (Perry, Wood, \& Fernie, 2015). In these cases, the suppliers adopt the codes as a window-dressing strategy to appease the buyers (factory manager, personal communication, 2014). At the same time, buyers use CSR to create a good-citizen image, to form good relations with activists, and to avoid brand naming and shaming exposures, but continue to use sourcing squeeze techniques to increase the profit margin of their companies.

The fashion industry occupies a distinctive place in the developing world's clothing industry, and as such warrants particular attention (White, Neilsen, \& Valentini, 2017, p. 390). It consists of large numbers of brand-name corporations and large retail chain stores whose business model is to source cheap garments, while maintaining a marketing edge that allows them to make exhorbitant profits far beyond what is reflected in the costs of production. The call to bridge the gap between fashion and workers was articulated in the late 1990s when McRobbie (1997) argued that there was an avoidance of questions of poverty and hardship in clothing production and on those who work at producing consumption.

This article attempts to bridge the gap by using theories from Cultural Studies, International Political Economy (IPE) and Ethics and Business Management to connect the fashion industry and brand-name capitalism to the international division of labour and CSR. We need to use cultural studies so we can understand consumer consumption, fashion fetish and consumer blindness to poverty in developing countries. It is necessary to tease out the tensions between the aspirations of fashion corporations and the ability of CSR to address poverty and worker 
exploitation. The paper is divided into five sections. First it outlines the structure of global commodity chains to situate brand-name consumer campaigns within the international political economy. The next section provides an overview of how fashion desire and overconsumption are created by corporations while at the same time patterns of labour exploitation are made invisible, leading to the anti-sweatshop movement and the subsequent introduction of CSR. In the third section I summarise the evolution of corporate governance and CSR. This section explains why the stakeholder CSR model has not moved beyond its initial introduction of codes of conduct and is problematic in delivering adequate labour standards. The next two parts present a case study of a brand-name cause-related marketing strategy that provides an excellent corporate citizen image that gains public and social legitimacy. But then I juxtapose corporate philanthropy against the exploitation of large numbers of workers in the clothing industry in Bangladesh and Bangladeshi workers in Malaysia to show its limitations. This section highlights the gap between CSR and codes of conduct in improving the position of precarious Bangladeshi and migrant workers in Malaysia.

\section{Globalisation and Commodity Chains}

Globalisation and neoliberal trade policies have created higher levels of competition in the clothing industry, leading to the disorganisation of labour and increasing levels of labour abuse in developing countries (Crinis \& Vickers, 2017). Global manufacturing increased after the Multi-Fibre Arrangement (MFA) in 1974 allocated a greater quota of clothing production to emerging economies. By the 1980s, manufacturers in developed countries moved their production to suppliers in developing countries, corresponding with the changes in consumer demand. By the time the quota system ended in 2004 under the World Trade Organisation (WTO), competition in the industry had shifted to almost every corner of the world. The United Nations (2013) estimates that four-fifths of global trade is integrated into transnational corporation production networks, with up to a third of the global trade bound into crossborder supply networks. For instance, Nike has its clothes and shoes made in 591 factories in 42 countries and these facilities employ more than 1 million workers (Nike Inc., 2017).

The theories of global commodity chains (GCC)/global production networks and global value chains have been used to explain how the global industry works (Coe, Dicken, \& Hess, 2008; Coe \& Yeung, 2015; Gereffi \& Korzeniewicz, 1994). In GCC analysis, the global garment industry is buyer-driven. The buyer designs and markets the clothing and the suppliers - mostly in developing countries - produce the garments. The brand-name buyer does not own the factory and has no responsibility to the factory workers, yet power is located with the buyer who creates high levels of competition on the margins, pushing wages down as suppliers compete for contracts. There are more nuanced versions of power along the commodity chain exemplified in the way Taiwanese and Korean companies have set up large supply facilities in China to supply garments to chain stores and small and medium enterprises (Appelbaum, 2008). In this case, the supplier of full-package production is stronger than the smaller buyers, but in most cases, the power lies with the brand-name buyers, especially buyers using high levels of technology in their business strategies (Gereffi \& Memedovic, 2003). Company profits increase using information technology that permits companies to recognise the market trends and then construct a new market to be exploited (Dyer-Witheford, 2010). Electronic data exchange allows companies to set the standards in the industry regarding quality, price and speed of response (Collins, 2003).

Most of the literature tends to question the benefits of GCC production for developing countries. Skills-transfer appears to be more common in countries where manufacturers 
produce for the high end of the market. In general, countries where manufacturers produce for the mass market are more likely to face fierce competition and workers in these factories are more likely to experience "sweatshop" conditions. Since the 1990s, social movement organisations (SMOs) - known more commonly as the anti-sweatshop movement - have taken the place of unions stimulating the growth of consumer interest. Northern-based activism exposes labour exploitation in brand-name supply factories and uses public campaigns to attempt to persuade consumers to boycott these brand names. Because global corporations invest heavily in their fashion brand, anti-sweatshop exposure has the potential to damage retail business.

\section{Corporate Fashion: Retail Giants and Brand Names}

Retail and brand-name managers realise that building an image is more important than making capital in their factories because the commodification of "signs" and fashion names allows manufacturers to sell shoes and garments far beyond the cost of production. According to Baudrillard's political economy of signs, the difference in the cost of a brand name and a noname garment is not in the material or the labour but the "value-added" of the sign (Kellner, 1994). Baudrillard's concept traced the life of signs and impact of technology on social and everyday life, and he was particularly interested in the fashion industry. He argued that during the 1980s competitive market capitalism moved to monopoly capitalism, which included increased attention to the management of consumption and the creation of the desire for the need for new clothes. Brand-name companies employ the best knowledge workers to produce the brand sign, and advertising agencies promote fashion brand icons to signify meaning to a particular group of consumers often based on youth, ethnicity and sexuality (Perez \& Bairon, 2013). Commodity capitalism goes hand in hand with the expansion of brand-name retail stores. For Zara and H\&M, the use of the internet and program technology has allowed for the restructuring of the garment industry to sell smaller batches of brand-name goods to a specific sector of the population (Gill \& Pratt, 2008). Zara and H\&M make more profit stocking their stores every six weeks (Crewe \& Goodrum, 2000) than producing garments around the seasons. ${ }^{1}$ Consumers visit these stores at least four times more than other fashion stores.

The general shift from material to immaterial production reflects a general transformation in the business logic of the fashion industry from an emphasis on creativity and production to a focus on communication and brand. In this context, fashion requires publicity to convince people before clothes become a fashion (Loschek, 2009, p. 150). In this era of modernity, creating brands, using advertising and fashion web designers, and using financial expertise and excel programs for the collation of sales and production has led to a substantial increase in immaterial labour versus the material part of the value chain. The fastest-growing sectors have created larger numbers of knowledge/cultural workers (Wark, 1991; Weller, 2004). The workers employed by large corporations are rewarded for their creativity, but there are numbers of creative students and small businesses that support the creative side of the industry. These people and students work from home and are paid an hourly rate with few if any work benefits. They work long hours in the hope of having their creative talents discovered and getting a decent job and becoming famous in the industry (Lazzarato, 2011, p. 134).

With the focus on creativity and consumption, there are few ways to connect fashion industry to the production workers. Nevertheless, the anti-sweatshop movement has focused on brand capitalism and drawn attention to the lives of workers in developing countries through naming and shaming strategies. In these instances, the internet has worked in favour of activism against corporate fashion. Nike is an example where the organisation of capitalism is around sign value 
rather than use value and where the sign was outed by the anti-sweatshop movement (Sittamparam, 2008). ${ }^{2}$ Nike developed a sign - the "swoosh sign" - and due to massive advertising campaigns commencing in 1984 the company became famous with consumers when it signed the 21-year-old Michael Jordan to endorse basketball sneakers. Sports shoes sold far above the cost value and generated huge profits, motivating investors to buy Nike shares. Nike captured the attention of consumers after the brand name was outed by the antisweatshop movement in the 1990s. ${ }^{3}$ The Nike experience had a significant impact at the time. Brand-name companies fearing the worst insisted their suppliers sign up to brand-buyer accreditation systems including the US-based Apparel Industry Partnership, Social Accountability International, and World Wide Responsible Apparel Production, for annual monitoring and factory certification to appease consumers. Other companies employed independent corporate initiatives and devised company codes to ward off brand-name damage as opposed to supporting improved working conditions and allowing workers to join worker associations.

\section{Corporate Models: Shareholders to Stakeholders}

Corporate governance is the process and structure used to direct and manage the business affairs of a company. The Organisation for Economic Cooperation and Development (OECD) defines corporate governance as the system by which business corporations are directed and controlled. It involves the set of relations between a company's management, its board, its shareholders and its stakeholders (OECD, 2017). CSR is a management strategy used for numerous reasons: to create a respectable corporate image, to generate support from social and environmental activists, to signal their product quality in a highly competitive environment, and to reduce conflict between investors, managers and non-investing stakeholders (Harjoto \& Jo, 2011). This section aims to highlight how corporate governance started with the needs of business but after the production process moved offshore, corporate governance managers included CSR and codes of conduct in the management of commodity chain production. The rise of CSR as a business governance strategy shows that the history of CSR does not belong in the realm of labour rights and human rights. In fact, the history of CSR covers up the long national labour struggles of the past and makes CSR a system whereby workers can access good working conditions at the same time as legitimising poor working conditions as typical in developing countries (Wheeler, 2015). To understand CSR initiatives, ethical and business management scholars Garriga and Mele (2004, p. 51), Scherer and Palazzo (2011) and Banerjee (2014) provide a table and concepts to broadly classify the current theories and the approaches related to CSR. Corporate governance can be divided into three historical phases: the shareholder model, the stakeholder model and the more recent ethical model. In the current period, the ethical model, which encompasses the Global Compact, marked the beginning of global governance coming to terms with labour exploitation in commodity chains.

\section{The shareholder model}

The shareholder model focuses on the maximisation of shareholder value with the emphasis on strategies for competitive advantage such as moving to low-wage countries and cause-related marketing (discussed below). The shareholder approach draws on property rights theory and agency theory to give primacy to the agency in the appropriation of wealth generated by large brand-name companies (Palpacuer, 2009, p. 283). The state plays a limited role in the market, and the market provides its regulatory system. A central claim of the shareholder view and the foundation for its social legitimacy lies in the notion that maximising shareholder value provides the best avenue for maximising the economy as a whole and improving social welfare 
(Garriga \& Mele, 2004, p. 52). This shareholder perspective sees the role of stakeholders and unions and collective worker action as contrary to the free market. Under this model, the corporation has no responsibility to society (Palpacuer, 2009, p. 282). According to Bakan (2004), the corporate mission will always be profit at the expense of workers.

In the 1960s, the shareholder model was criticised for not acting in good faith for the benefit of politics and business. Business scholars started to call for theories on business and social responsibility to evaluate how a corporation should act regarding social demands, ethics, profits and politics (Garriga \& Mele, 2004). The call for political theories to ensure the responsible use of business power in the political arena regarding proper Corporate Constitutionalism and Corporate Citizenship started to gain ground (Garriga \& Mele, 2004, p. 55). By the 1980s, an Integrative Social Contract Theory for business to be responsible for maintaining legitimacy from the community was put forward (Garriga \& Mele, 2004, p. 57). In this theory, the corporation must strive for profit accumulation but at the same time legitimate its role in society by providing welfare. The corporate citizen was promoted as a substitute for the welfare state.

\section{The stakeholder model}

Global corporate behaviour was taken seriously by the various business interests in the 1980s - especially by companies listed on the stock market. According to business management theory, the integrative method builds on the integration of business interests and the social demands of the stakeholders. Stakeholder-oriented governance supposedly boosts economic performance and improves social welfare. Unlike the shareholder model, the integrative model includes stakeholder management, corporate social performance and issues management (Garriga \& Mele, 2004).

In the clothing industry, the stakeholder model led to the adoption of codes of conduct and an in-house monitoring system because the value of the brand depends on consumers' perception of responsible behaviour. In the stakeholder model, the company also uses a naming and praising approach to address problems within the factories. The stakeholder model has created an industry of organisations, consultants and auditors alongside training programs, conferences and business schools. Most global industries and companies have remained partly within the CSR instrumental, political and integrative models despite their limitations in addressing workers' rights in global commodity chains. What is especially significant is that in all these models it is assumed that the privatisation of labour rights works well for workers and that the free market is the best way to provide for society (factory manager, personal communication, 2008). In the stakeholder model, global brand companies monitor the supply factories using an auditing company or accounting firm and shy away from using clothing and textile trade unionists or labour NGOs - for obvious reasons. These auditing companies know little about what to look for in a clothing factory and rely on a tick-box report.

\section{The ethical model}

Since the 2000s, the moral demands of investors, company shareholders, pension and ethically invested fund managers have made the integrative and ethical model more popular with MNCs (Garriga \& Mele, 2004, p. 61). The ethical model includes the buyer, the supplier and various worker representatives such as SMOs and anti-sweatshop activists. Meetings are held with different stakeholders to help brand-name companies to understand the general environment and the dilemma facing the company and then to balance these competing forces. While the ethical stakeholder models are considered to have better outcomes for workers, the power 
relations between corporations and developing country governments will inevitably affect how these tensions are resolved, especially in regard to monitoring and achievability. On a more positive note, unlike the stakeholder model, the ethical model uses independent auditors, such as the Ethical Trading Initiative and the Workers Rights' Consortium, to report on worker issues within the factories.

\section{Global governance and the Global Compact}

Since the erosion of state sovereignty, the decline of worker organisations (trade unions) and the globalisation of labour, a political movement has worked towards gaining political cooperation among transnational actors which include the United Nations and the Global Union Federations to advocate for labour rights in supply chains (Finkelstein, 1995). The political movement started in the 1990s at a protest in Seattle. During this rally, corporate accountability movements joined forces to bring labour rights into world trade discussions and to re-establish the social responsibility of brand-name companies to workers in their supply chains (Barrientos, 2013). ${ }^{4}$ As part of their duty to workers, the United Nations and the ILO introduced the Global Compact at the World Economic Forum in 1999. The Global Compact goes beyond instrumental politics and pushes for global governance based on private actors such as corporations and civil society organisations that play a role in the democratisation of business. The Global Compact is the world's largest CSR initiative developed with over 8,000 corporations and 4,000 non-business participants based in over 160 countries (United Nations, 1999). The framework calls for companies to "protect, respect and remedy" and includes anticorruption, human rights, labour rights and environmental protection. This structure means that the corporation, as well as the state, must protect workers within the human rights framework (Wheeler, 2015). The Guiding Principles have a Due Diligence clause that calls for companies, both small and large, to exercise due diligence to avoid complicity in labour abuses and environmental destruction. For the ILO, this means that business enterprises must facilitate the avoidance of any adverse human rights impacts that their decisions may have on workers. The Global Compact model is inclusive of stakeholders and leans towards sustainable development and the common-good approach, which maintains that business has to contribute to the common good of the community in creating wealth, providing goods and services and at the same time respecting the inalienable and fundamental rights of the individual. ${ }^{5}$ The protect, respect and remedy model built into CSR was intended to push corporations into moving from the era of introducing codes of conduct to corporate respect for human rights, but most nonEuropean companies have been slow to adopt the United Nations Global Compact. Their reluctance stems directly from the profit-seeking objectives of clothing brand-name companies and retail giants, but possible new exposure to lawsuits is also a significant consideration.

At present, sustainable development and sustainable production are taking centre stage under the 17 Sustainable Development Goals introduced in 2015. Goal 8, Target 8 calls on companies, governments and trade unions to join forces in the protection of labour in global supply chains. The ILO calls for a return to the tripartite system of consultation between government, capital and unions, but this is of questionable value considering that most manufacturers source from supply chains in developing countries to escape organised workers in their home countries. Managers and CEOs prefer to employ cause-related marketing to create a good corporate image and use codes of conduct and stakeholder roundtable discussion rather than involve trade unions despite the fact that few workers ever attend the meetings (Tenaganita, personal communication, 2014).

\section{Cause-related Marketing and the Girl Effect}


Cause-related marketing has increased in recent years. Brand-name companies improve the company image by investing in charitable pursuits in developing countries. These initiatives offset anti-sweatshop campaigns and keep consumers on their side (Tsing, 2009, p. 164). By funding sporting events, health promotions and charitable institutions, companies are considered to be "ethical" corporations producing justice. Nike, for example, has developed a cause-related marketing business model to address development and poverty through education, sport and skills enhancement in Bangladesh and Africa. Creating a good corporate citizen image has been called “smart economics” (World Bank, 2012). Nike's “girl effect” was launched at the World Economic Forum in Davos 2009 after Michael Knight (Nike) and Peter Buffet joined forces to help girls (Nike Inc., 2008). Nike has a leadership team that works with various corporate partners and governments in Bangladesh and Africa to improve the situation of girls. Poor girls became a Foundation priority. ${ }^{6}$ Nike focused on girls because the general observation is that girls contribute more of their income to the household than males (if they have a job). So by helping girls gain an education, the Foundation will be assisting more girls to find better-paying jobs to support their families. This is considered to be a way of ending the poverty cycle. The Foundation also encourages girls to take up a sport as well as producing a magazine-type website for teens in various African nations (mostly directed at an emerging modern consumer group). According to Maria Eitel, the "girl effect brings to life a powerful idea [that] the least powerful person on the planet can transform it" (cited in Bermudez, 2011, p.1). Eitel is the founding President and CEO of the Nike Foundation. Before the Foundation, Eitel served as Nike's first Vice President of Corporate Responsibility, where she developed and implemented the company's first corporate social responsibility agenda. For Nike, the girl effect campaign aims to build good relations with perceived customers by showing the company's involvement in philanthropy. Nike strongly denies that the girl effect was established to offset consumers' concerns (Elliott, 2010). According to a Good Purpose Survey, however, the girl effect rated Nike in the top three companies which placed as much importance on supporting a good cause as on making a profit (Elliott, 2010). Nike interventions in sports, gender and development are part of the portfolio of CSR initiatives in International Development (DeNeve, 2008).

Hayhurst (2011) has provided a critical lens suggesting three themes that speak to the colonialist residue within CSR interventions: the economic power of brand-name companies, the importance of the powerless female "third world" victim, and the politics of the "global" sister enmeshed in saving poor women. According to Hayhurst (2011), brand-name philanthropic endeavours such as the girl effect assume that female workers and girls in Bangladesh lack agency. In the girl effect, there are no female voices: women appear as victims. Siddiqi (2009, p. 159) argues, in the same light, that the unfortunate female victim in Bangladesh is a western construct to engage the consumer and produce the good global citizen perspective. She argues that denying these women a voice is another form of violence against women. According to Roberts (2015, p. 209), Nike is promoting a naturalised and essentialist view of women and poverty and gender-based inequality. This type of philanthropy reproduces the same neoliberal framework that has created and sustained gender-based and other forms of oppression via the global feminisation of labour (Roberts, 2015).

Thus the term "cause-related marketing" means that companies donate money towards the cause and at the same time establish a potential consumer market. They peddle modernity, sport and fashion to a select group of girls through social media (teen magazines and websites), hoping to establish a future consumer market. In countries such as Bangladesh, women want access to education and decent work, but for all women and girls, not just a select few. 
Nevertheless, despite brand-name philanthropy, Bangladeshi women and girls maintain their agency. In fact, labour intensive manufacturing in the export industries has occurred on the backs of women and girls.

\section{Female Bangladeshi Workers and Global Production in Bangladesh}

Female workers make a considerable contribution to Bangladesh's Gross Domestic Product. Some 4,536 garment factories employ more than four million workers, mostly young women. In 2013-14, clothing exports worth US\$24 billion made up three-quarters of the country's exports, and this figure continued to grow. Most workers earn around US\$70 per month with overtime. But this is hardly enough considering that rent for a family of three costs US\$40 per month, and food costs US\$50 per month (Migration News, 2013). Both the government and suppliers are fearful that buyers will leave Bangladesh for another low-cost location, so the cost factor remains in the realm of the purchaser. Bangladesh is in a no-win situation as the country is prevented from moving to higher value-added garment production due to the 34 previous trade agreements it signed with the WTO (Siddiqi, 2009). In other words, the industry in Bangladesh has few opportunities to increase profits to pay higher wages and in turn for the state to earn extra income tax to provide better infrastructure and public services.

After the Rana Plaza building collapse on 23 April 2013 killed 1,135 workers and injured another 2,000 - many of them clothing workers - a discussion started on the benefits of export manufacturing: whether sewing jobs that offer a low wage were helping to reduce poverty or adding to poverty and dangerous conditions for poor workers (Curran \& Nadvib, 2015). Commodity chain production for fast fashion places extreme pressure on employees and suppliers and, in turn, suppliers have to find the fabric and inputs to produce the full-package production and dispatch the order by the contract date or pay the transportation costs. The workers have to work harder and longer to meet the contract date. ${ }^{7}$ While many of the building structures housing the workers are below building standards in Bangladesh, little is done to address these dangers because suppliers are pushing to meet the fast-fashion deadlines, there is little maintenance on the buildings, and new buildings are erected without appropriate building approval to meet the demands of economic development.

In response to the Rana Plaza collapse, Bangladeshi workers took to the streets to demand action against the builder and the labour-contracting system. So far, charges have been laid against 41 Bangladeshi builders and employers. Brand-name buyers have also endorsed workplace health and safety by signing an Accord on Fire and Building Safety. The Accord is an agreement between brand names and trade unions to monitor workplace safety and to take financial responsibility by contributing money each year to a contribution fund for the families of the deceased workers. European companies such as Zara and H\&M have endorsed the agreement, but the US companies ignored the meetings held to discuss compensation to the families of the Bangladeshi women killed in the Rana Plaza disaster. GAP and Walmart preferred to write up a corporate-controlled sham Agreement. According to CCC, instead of joining the Accord, GAP, together with Walmart, created the Alliance for Bangladesh Worker Safety (CCC, 2014). Despite sounding promising, the CCC claims this initiative is not legally binding and includes no union involvement, making it hardly more than a PR stunt to dodge safety responsibility. In this respect, the company portrays a public image of being a leader in responsibility while actively undermining CSR to protect, respect and remedy.

Most brand-name companies use Bangladesh in their supply chains because the country can produce at short notice, and labour is cheap. Buyers are not going to leave because production 
costs in Bangladesh are favourable to the market. For example, the buyers pay around US\$7 to have a shirt made, leaving the supplier to pay US\$5 for fabric, US\$1 on labels and buttons and US\$1 for sewing as well as shipping and profits (Migration News, 2013). Walmart imports US\$1 billion worth of garments per year from Bangladesh. Nike operated five factories in Bangladesh making mostly sports apparel and employed 22,800 female workers. Since the Rana Plaza tragedy, Nike has reduced its operations in Bangladesh to two factories employing 6,423 workers because Nike is concerned with protecting its brand image (Nike Inc., 2017). $\mathrm{H} \& \mathrm{M}$ is the largest purchaser of garments from Bangladesh, and stocks its numerous retail stores with cheap clothes.

It is highly unlikely that CSR will allow a change in the pricing and sourcing structures of the industry because these decisions are made in the marketing department. If corporations are serious about ensuring good labour standards in their supply chains, they have to address the issues around fast fashion, and move beyond the notion that profit is the bottom line, paying suppliers sufficient money for garment production. The low-wage policy in Bangladesh is hardly enough to sustain a worker, let alone a family. Most workers complain that without working extra hours they have difficulty meeting their family's costs of living. Despite the fact that workers protest and strike it has made little difference. Wages have remained virtually the same for some time.

Unfortunately, the situation in Bangladesh has pushed both female and male workers to seek higher-paying jobs overseas in places such as the Middle East and Malaysia. While some migrant workers find jobs that offer better wages and conditions than in Bangladesh, this is not always the case. The problems migrant workers experience are well documented, especially in the context of trafficking in persons in Malaysia (Tenaganita, 2008). The next section looks at the situation of Bangladeshi workers in Malaysia.

\section{Export Manufacturing and Migrant Workers in Malaysia}

The state in Malaysia is a developmentalist state and has specific labour conditions in place to benefit the export industry at the expense of labour. The employment of foreign workers has helped Malaysia to overcome the loss of its competitive advantage (Crinis, 2012). Since the 2000s, Malaysia has been subjected to high levels of competition from low-cost countries such as Bangladesh, China and Vietnam. As part of economic development, the government has allowed overseas migrant workers into the low-paid export sector - both agricultural exports and manufactured exports, including electronic components, electrical goods, clothing and textiles. ${ }^{8}$ Since the 2000s, around 700,000 migrant workers have moved into the low-paying sectors of the manufacturing industry. In the clothing industry, migrant workers make up 80 per cent of production workers (Crinis, 2010). The government has had an on-off relationship with migrant workers, turning a blind eye to the numbers of migrants entering the country without the necessary papers and at other times organising push back programs to expel unauthorised migrant workers. In 2014, there were around 6.7 million foreign workers in Malaysia. Of that number, only 2.1 million possessed valid work permits and were registered with the Immigration Department (Sun Daily, 2016).

The government manages recruitment under two systems. The government-to-government programs with memorandums of understanding allowed for scores of workers to be recruited from Bangladesh, Cambodia, India, Indonesia, Nepal, the Philippines and Vietnam. Under the government-to-government system, workers are assigned to one employer. The employer must obtain a work permit from the government and generate a contract with the name and address 
of the employer and the signature of the worker, including specification of the working conditions.

The second system, known as the outsourcing system, allowed companies requiring fewer than 50 employees to use outsourcing companies. These companies sub-contract workers to the manufacturing industries and under this system the outsourcing company is the employer. In the clothing industry, this means that the worker is not employed by the brand-name buyer or by the supplier, so codes of conduct have little if any significance for migrant workers. Since 2005, the outsourcing system has allowed for corruption around migrant labour and more precarious forms of labour recruitment coming from Bangladesh and Myanmar. ${ }^{9}$

Although supposedly protected under the UN International Convention for the Protection of the Rights of All Migrant Workers and Members of Their Families, migrant workers in Malaysia are rarely accorded protection in the workforce or society. Sending countries such as the Philippines have made it a priority to protect their nationals. Sending countries such as Bangladesh and Indonesia are more likely to ratify the Convention, but receiving countries such as Malaysia have in part agreed to the Convention but not to the rights of the migrant's family. Martin Ruhs (2015) argues that those classified as low skilled find that the denial of their rights is the price of admission to guest worker immigration programs. Likewise, Tsing contends that the conditions of contracting through supply chains stimulate the performance of niche workforces of rural migrants and transnational migrants whereby employers can apply super-exploitation strategies (Tsing, 2009, p. 167). The specially designed immigration policies allow private recruitment and outsourcing companies to charge exorbitant costs for travel and workplace documents. As a result, workers borrow money (at high interest rates) for transport to Malaysia, and are usually in debt to their parents or a recruitment company.

The contract and work permit are legal documents and place certain restrictions on the worker. Workers are on short-term contracts and must return to their country of origin after they complete their contract, and they are not allowed to bring family members with them or to get pregnant. If pregnancy is detected, the woman is sent back to her country of origin. Migrants employed on two- and three-year contracts work six days per week, 12 hours per day without annual holidays. Migrant workers are officially allowed to join trade unions in Malaysia, but many barriers are put in their way, in some cases by the government and in other cases by local unions. The barriers to joining a trade union include employment specifications set out in the contract. There are also government sanctions on the right to participate in trade unions in particular economic export sectors, which means there are no unions in the factory for migrant workers to join.

Despite such deterrents, there are clothing and textile trade unions in each state, but workers have few prospects of changing employers to move to a plant with a trade union. According to the work permit, if a worker leaves their place of employment the permit is cancelled, and the migrant worker becomes an illegal worker subject to arrest, incarceration and deportation (Nah, 2012). The government charges a fee to hire a foreign worker, so the employer stands to lose money if the worker absconds from the factory. In retaliation, employers force conditions of coercion on their workers by removing their passports (despite this being illegal) and holding back wages to stop them from fleeing. As "legal" migrants attempt to avoid this type of coercion, they often leave the employer and this, in turn, leads to problems of illegality. Some scholars argue that being "illegal” allows migrant workers more freedom to move around, but this creates the opening for another type of coercion (Schrover et al., 2008). The demand for new passports and work permits for "illegals" allows opportunists to charge exorbitant amounts 
for new documents, pushing migrant workers further into debt, and the cycle of coercion continues. So workers may start out as documented workers but end up as "illegal" workers owing more money than they did before coming to Malaysia and subject to debt bondage.

Migrant workers, however, have been responsible for most of the labour protests between 2000 and 2015. In 2002, Indonesian workers in a textile factory in Nilai in the state of Negeri Sembilan, Malaysia rioted over unfair labour practices (Murali, 2002). Instead of addressing their complaints, the Malaysian government responded by increasing the number of Bangladeshi and Vietnamese workers allowed to apply for work permits at the expense of Indonesian workers. The government used the same tactic after Vietnamese workers rioted. After this, the government increased the number of Nepalese workers in the manufacturing industry. Several more wildcat strikes erupted over the failure of employers to pay the minimum wage to migrant workers (Fernandez, 2014; Vietnam News, 2013).

Despite these conditions and such discrimination, migrant workers continue to come to Malaysia. As Tsing points out, workers believe that these conditions, although exploitative, will lead to a business of their own. They imagine themselves working hard for three years and then going home with money to start their own business (Tsing, 2009, p. 167). Cultural characteristics such as gender, ethnicity and religion also make it possible for migrant workers to motivate their relatives or neighbours in their home villages in Nepal and Bangladesh to come to Malaysia for work. In this respect, self-exploitation driven by gender, race and national performance standards is all too prevalent. On the demand side, suppliers are keen to employ migrant workers because they are a disposable workforce compared to citizen workers. There is no penalty for dismissing a guest worker. Employers also use ethnicity by linking ethnic performance to economic performance and selecting the ethnicities more suited to clothing production.

In Malaysia, according to the clothing suppliers, brand-name buyers such as Nike and Adidas are very concerned about labour rights abuses in their supply factories and insist on suppliers adopting codes of conduct. CSR code-monitoring does not track workers abused by outsourcing companies. The denial of these human and labour rights is invisible to CSR auditors. Violations continue, mostly unchecked, and many of the issues that affect migrant workers are not even covered by many of the codes, much less uncovered by monitoring (LeBaron \& Lister, 2015). The unchecked violations relate to the employment contract in general. More specifically, violations include unfair dismissal, underpayment of wages, withholding wages, the right to join a trade union, injuries at work, and the right to compensation. Sundra-Karean, Suhnh and Ahmad (2012) argue that big global corporations such as Nike will eventually put pressure on Malaysian supply companies to address the exploitation of migrant workers or risk being dumped by the buyer. But this has not occurred despite a great deal of publicity surrounding migrant-labour abuse in Malaysia.

\section{Conclusion}

Corporate governance and the introduction of CSR and codes of conduct is a positive move, but it has failed to address the gap in labour protection for some of the most vulnerable workers in Asia. While the production of goods crosses borders, workers also cross borders to find employment in brand-name commodity production, but corporate fashion is the benefactor. To make the industry more equitable for production workers at the micro level, corporate buyers must employ ethical initiatives to educate suppliers and use trained monitors to enforce transparency from the bottom up. Local workers and trade unions, as well as NGOs, should be 
included in the monitoring of the codes. The codes must be more specific to include both local and migrant workers. In the case of overseas migrant workers, the anti-discrimination code should be teased out to include unfair dismissal and the right to join a trade union. Most importantly, the codes should also include a wage structure agreed on by both worker organisations and the government. An increase in the wage structure will address poverty and augment worker productivity and factory performance and should be the preferred option.

At the macro level, global institutions under the United Nations called on companies to adopt the Global Compact, but many firms are not willing to sign agreements that may lead to corporate lawsuits. In this case, all stakeholders and social movement organisations will need to band together and move away from the soft glove approach. In other words, global governance needs to be more rigorous, guiding companies from the stakeholder model to an ethical practices model. Whether this is an option remains to be seen. Corporations blame the state for not enforcing proper labour standards. In some cases, the company pushes the nationstate to be complicit in allowing a low-wage structure to continue, as is evident in Bangladesh. In the case of developing countries, the buyer can threaten the nation-state with capital flight, enhancing its power over the state and local suppliers, but this needs to change. As Angie Ngoc Tran and Soren Jeppeson (2016) pointed out in their article on Vietnam and CSR, there is a need to increase state government activity in regards to the privatisation of labour codes to protect and empower workers.

It has been 20 years since McRobbie called for scholars to bridge the gap between the fashion industry, consumers and low-paid workers in developing countries. This has become more difficult as corporations have created a further divide by promoting CSR, which normalises "poor" workers in developing countries and highlights the benevolent company bringing justice to the developing world. The corporations construct workers as weak and in need of CSR. At an academic level, bringing fashion, economics and global commodity chains together is challenging, but it is crucial to show how corporate fashion is promoting overconsumption of brand-name designs and cheap retail clothes to create high levels of profit for publicly listed companies and their shareholders. The competitive nature of the industry pushes labour costs to a minimum, which in turn affects the supply chains, small family businesses and the workers. Production workers are invisible. By crossing disciplines, the article highlights the ways in which creative industries provide a spectacle to distract the consumers from commodity chains and production workers, and opens the door to further research in this field.

\section{Acknowledgments}

The author would like to acknowledge Professor Vera Mackie (Centre for Critical Human Rights Research), editors of Asian Studies Review and two anonymous reviewers for their generous comments and suggestions.

\section{References}

Appelbaum, R. (2008). Giant transnational contractors in East Asia: Emergent trends in global supply chains. Competition and Change, 12(1), 69-87.

Bair, J., \& Palpacuer, F. (2015). CSR beyond the corporation: Contested governance in global value chains. Global Networks, 15, 1-19. 
Bakan, J. (2004). The corporation: The pathological pursuit of profit and power. London: Constable \& Robinson Ltd.

Banerjee, S. B. (2014). A critical perspective on Corporate Social Responsibility. Critical Perspectives on International Business, 10(1-2), 84-95.

Barrientos, S. (2013). Corporate purchasing practices in global production networks: A socially contested terrain. Geoforum, 44, 44-51.

Bermudez, C. (2011) Nike's charity fund seeks to unleash the "girl fffect". Chronicle of Philanthropy, 24(2), 1-2.

Clean Clothes Campaign (CCC). (2014, 23 January). Public Eye Awards 2014: GAP receives "award of shame”. Retrieved from https://cleanclothes.org/news/2014/01/23/public-eyeawards-2014-gap-receives-award-of-shame

Coe, N., Dicken, P., \& Hess, M. (2008). Global production networks: Realizing the potential. Journal of Economic Geography, 8, 271-295.

Coe, N., \& Yeung, H. W.-C. (2015). Global production networks: Theorising economic development in an interconnected world. Oxford: Oxford University Press.

Collins, J. (2003). Threads: Gender, labour and power in the global apparel industry. Chicago: University of Chicago Press.

Collins, J. (2014). A feminist approach to overcoming the closed boxes of the commodity chain. In W. A. Dunaway (Ed.), Gendered commodity chains: Seeing women's work and households in global production (pp. 27-37). Stanford: Stanford University Press.

Crewe, L., \& Goodrum, A. (2000). Fashioning new forms of consumption. In S. Bruzzi \& P. Church Gibson (Eds.), Fashion cultures: Theories and analysis (pp. 25-48). London: Routledge.

Crinis, V. (2010). Sweat or no sweat: Foreign workers in the garment industry in Malaysia. Journal of Contemporary Asia, 40(4), 589-611.

Crinis, V. (2012). Global commodity chains in crisis: The garment industry in Malaysia. Institutions and Economies, 4(3), 61-82.

Crinis, V., \& Vickers, A. (Eds.). (2017). Labour in the clothing industry in the Asia Pacific. London: Routledge.

Curran, L., \& Nadvib, K. (2015). Shifting trade preferences and value chain impacts in the Bangladesh textiles and garment industry. Cambridge Journal of Regions, Economy and Society, 8, 459-474.

DeNeve, G. (2008). Global garment chains, local labour activism: New challenges to trade unionism in the Tiruppur Garment Cluster South India. In G. DeNeve, P. Luetchford, J. Pratt, \& D. C. Wood (Eds.), Hidden hands in the market: Ethnographies of fair trade, ethical 
consumption and Corporate Social Responsibility (pp. 213-240). Bingley: Emerald Group Publishing Limited.

Dyer-Witheford, N. (2010). Empire, immaterial labour the new combinations and the global worker. Rethinking Marxism, 13(3-4), 70-80.

Elliott, S. (2010, 11 November). Nike harness “girl effect” again. New York Times, p. 12.

Esbenshade, J. (2012). A review of private regulation: Codes and monitoring in the apparel industry. Sociology Compass, 6(7): 541-556.

Fernandez, C. (2014). Malaysia factory riots provide look at migrant workers' grievances. Retrieved from http://www.wsj.com/articles/malaysia-factory-riots-provide-look-at-migrantworkers-grievances-1409236485

Finkelstein, L. (1995). What is global governance? Global Governance, 1(3), 367-372.

Garriga, E., \& Mele, D. (2004). Corporate Social Responsibility theories: Mapping the territory. Journal of Business Ethics, 53, 51-71.

Gereffi, G., \& Korzeniewicz, M. (Eds.). (1994). Commodity chains and global capitalism. Westport: Praeger.

Gereffi, G., \& Memedovic, O. (2003). The global apparel value chain: What prospects for upgrading by developing countries? Vienna: United Nations Industrial Organisation.

Gill, R., \& Pratt, A. (2008). Precarity and cultural work in the social factory? Immaterial labour, precariousness and cultural work. Theory, Culture and Society, 25(7-8), 1-30.

Hale, A., \& Willis, J. (2007). Women Working Worldwide: Transnational networks, Corporate Social Responsibility and action research. Global Networks, 7(4), 453-476.

Harjoto, M., \& Jo, H. (2011). Corporate governance and CSR nexus. Journal of Business Ethics, 100, 45-67.

Hayhurst, L. (2011). Corporatising sport, gender and development: Postcolonial IR feminisms, transnational private governance and global corporate social engagement. Third World Quarterly, 32(3), 531-549.

Kellner, D. (1994). Baudillard: A critical reader. Cambridge: Blackwell.

Lazzarato, M. (2011). Immaterial labour. Retrieved from http://strickdistro.org/wpcontent/uploads/2011/09/Week-1_Immaterial-Labour_Lazzarato.pdf

LeBaron, G., \& Lister, J. (2015). Benchmarking global supply chains: The power of the ethical audit-machine. Review of International Studies, 41(5), 905-924.

Locke, R., Qin, F., \& Brause, A. (2007). Does monitoring improve labour standards? Lessons from Nike. Industrial and Labor Relations Review, 61, 3-31. 
Loschek, I. (2009). When clothes become fashion: Design and innovation systems. Oxford: Berg.

Lund-Thomsen, P. \& Coe, N. (2015). Corporate Social Responsibility and labour agency: The case of Nike in Pakistan. Journal of Economic Geography, 15, 275-296.

Marx, A. \& Wouters, J. (2016). Redesigning enforcement in private labour regulation: Will it work? International Labour Review, 155(3), 435-459.

McRobbie, A. (1997). Bridging the gap: Fashion, feminism and consumption. Feminist Review, 55, 73-89.

Migration News. (2013). South Asia: Migrants. Migration News, 20(3), 1-3.

Murali. (2002, 18 January). Indonesian workers go on rampage. New Straits Times, p. 5.

Nah, A. (2012). Globalisation, sovereignty and immigration control: The hierarchy of rights for migrant workers in Malaysia. Asian Journal of Social Science, 40(4), 486-508.

Nike Inc. (2008). Nike Foundation and Buffett join to invest \$100 million in Girls. Retrieved from http://news.nike.com/news/nike-foundation-and-buffetts-join-to-invest-100-million-ingirls

Nike Inc. (2016). NIKE, Inc. reports fiscal 2016 fourth quarter and full year results. Retrieved from http://news.nike.com/news/nike-inc-reports-fiscal-2016-fourth-quarter-and-full-yearresults

Nike Inc. (2017). Nike manufacturing map. Retrieved from http://manufacturingmap.nikeinc.com/

Organisation for Economic Cooperation and Development [OECD]. (2017). OECD corporate governance. Retrieved from https://www.google.com.au/search?rls=com.microsoft\%3AenAU\%3AIE-

SearchBox\&dcr=0\&ei=rsZmWuXYHYGG8wXXu7ewAg\&q=oecd+definition+corporate+go vernance\&oq=oecd+definition+corporate+governance\&gs_l=psyab.12..0j0i22i30k1l3.20578.25355.0.27626.21.21.0.0.0.0.291.3471.0j12j5.17.0....0...1c.1.64.p sy-ab..4.17.3461....0.kqKpJOgbo9Q

Palpacuer, F. (2009). Challenging governance in global commodity chains: The case of transnational activist campaigns for better work conditions. In P. Utting \& J. C. Marques (Eds.), Corporate Social Responsibility and regulatory governance: Towards inclusive development? (pp. 276-298). Hampshire: Palgrave Macmillan.

Perez, C., \& Bairon, S. (2013). The meta-discourse of contemporary brands and the indexing of consumption: A way to build bonds of meaning. Social Semiotics, 23(4), 570-586.

Perry, P., Wood, S., \& Fernie, J. (2015). Corporate Social Responsibility in garment sourcing networks: Factory management perspectives on ethical trade in Sri Lanka. Journal of Business Ethics, 130, 737-752. 
Prieto-Carron, M. (2008). Women workers, industrialisation, global supply chains and corporate codes of conduct. Journal of Business Ethics, 86, 5-17.

Rahim, M. M. (2017). Improving social responsibility in RMG industries through a new governance approach in laws. Journal of Business Ethics, 143, 807-826.

Roberts, A. (2015). The political economy of "transnational business feminism”. International Feminist Journal of Politics, 17(2), 209-231.

Ruhs, M. (2015). Price of rights: Regulating international labor migration. Princeton: Princeton University Press.

Ruwanpura, K. N. (2015). Garments without guilt? Uneven labour geographies and ethical trading - Sri Lankan labour perspectives. Journal of Economic Geography, 10, 1-24.

Santoro, M. A. (2015). Business and human rights in historical perspective. Journal of Human Rights, 14(2), 155-161.

Schrover, M., van der Leun, J., Lucassen, L., \& Quispel, C. (2008). Illegal migration and gender in a global and historical perspective. Amsterdam: Amsterdam University Press.

Scherer, A. G., \& Palazzo, G. (2011). The new political role of business in a globalised world: A review of a new perspective on CSR and its implications for the firm, governance and democracy. Journal of Management, 48(4), 899-931.

Siddiqi, D. (2009). Do Bangladeshi factory workers need saving? Sisterhood in the postsweatshop era. Feminist Review, 91, 154-174.

Sittamparam (2008, 5 August). Ministry to probe Nike claims of worker abuse. New Straits Times, p. 17.

Sun Daily. (2016). Govt can keep tabs on foreign workforce by legalising Pati, says unionist. Retrieved from http://www.thesundaily.my/print/349627

Sundra-Karean, V., Suhnh, S., \& Ahmad, S. (2012). The role of Corporate Social Responsiblity and soft law options in the protection of migrant workers' interests in host countres - the case of Malaysia. Asian Journal of Social Science, 40, 509-523.

Tran, A. N., \& Jeppeson, S. (2016). SMEs in their own right: The views of managers and workers in Vietnamese textiles, garments and footwear companies Journal of Business Ethics, 137, 589-608.

Tenaganita. (2008). Stop trafficking in persons: The revolving door: Modern day slavery refugees. Kuala Lumpur: Tenaganita SDN BHD.

Tsing, A. (2009). Supply chains and the human condition. Rethinking Marxism, 21(2), 148176. 
United Nations. (1999). United Nations Global Compact - Guide to Corporate Sustainability: Shaping a sustainable future. Retrieved from https://www.unglobalcompact.org/docs/publications/UN_Global_Compact_Guide_to_Corpor ate_Sustainability.pdf

United Nations (2013). World Investment Report 2013: Global value chains: Investment and trade for development. New York: United Nations.

Vietnam News. (2013). Vietnamese workers in Malaysia resume work after 5-day strike. Retrieved from http://vietnamnews.vn/in-bai/236730/vietnamese-workers-in-malaysiaresume-work-after-5-day-strike.htm

Wark, M. (1991). Fashioning the future: Fashion, clothing and the manufacturing of postFordist culture. Cultural Studies, 5(1), 61-76.

Weller, S. (2004). Fashion's influence on garment mass production: Knowledge commodities and the capture of value. Melbourne: Centre for Strategic Economic Studies, Victoria University.

Wheeler, S. (2015). Global production, CSR and human rights: The courts of public opinion and the social licence to operate. International Journal of Human Rights, 19(6), 757-778.

White, C., Neilsen, A. E., \& Valentini, C. (2017). CSR research in the apparel industry: A quantitative and qualitatve review of existing literature. Corporate Social Responsibility and Environmental Management, 24, 382-394.

World Bank. (2012). World Development Report 2012: Gender equality and development. Washington: World Bank. 
1. These retail chain stores are among the richest companies in the world. Zara is the fourth richest company in the world.

2. Nike has stores across the globe and is a very wealthy company - amassing US\$32.4 billion in 2016.

3. The anti-sweatshop movement commenced in the United States with university students raising the alarm over the production of university clothes made in sweatshops. They focused on Nike and its supply chains.

4. In the clothing industry, Women Working Worldwide (WWW) helped to organise the Clean Clothes Campaign (CCC) in 1989. The CCC consisted of numbers of labour unions and NGOs who developed a Code of Practice for the Apparel Industry based on International Labor Organisation (ILO) Conventions. Other, older social movement activist groups such as Oxfam (est. 1942) changed their focus and started to campaign against unfair labour practices in global supply chains. SMOs, however, have only had moderate success in facilitating improved labour conditions for workers (Barrientos, 2013, p. 50).

5. The Catholic approach includes everything for the common good of society, and the Japanese concept of kyōsei is understood as living and working together for the common good (Garriga \& Mele, 2004, p. 61).

6. Influenced by the UN Agenda, which highlights gender equity and women's empowerment, one of the eight Millennium Goals with a special emphasis on reducing violence against girl children, which in turn reflected the continued focus on the 12 Critical Concerns at the UN-sponsored Beijing Conference (1995) in the UN Convention on the Elimination of All Forms of Discrimination Against Women.

7. The supplier is required to deliver the order to the seaport on the due date or the company has to pay the shipping costs.

8. Numbers of migrants mostly from Indonesia started to move to Malaysia in the 1970s. 